\title{
Graptemys pearlensis Ennen, Lovich, Kreiser, Selman, and Qualls 2010 - Pearl River Map Turtle
}

\author{
Joshua R. Ennen ${ }^{1}$, JeFFrey E. Lovich ${ }^{2}$, AND Robert L. JoneS ${ }^{3}$ \\ ${ }^{1}$ Tennessee Aquarium Conservation Institute, \\ 201 Chestnut Street, Chattanooga, Tennessee 37402 USA [jre@tnaqua.org]; \\ ${ }^{2}$ Southwest Biological Science Center, U.S. Geological Survey, \\ 2255 North Gemini Drive, Flagstaff, Arizona 86001 USA [jeffrey_lovich@usgs.gov]; \\ ${ }^{3}$ Mississippi Department of Wildlife, Fisheries, and Parks, Museum of Natural Science, \\ 2148 Riverside Drive, Jackson, Mississippi 39202 USA [bob.jones@mmns.state.ms.us]
}

Summary.-The Pearl River Map Turtle, Graptemys pearlensis (Family Emydidae), is a moderatesized aquatic turtle endemic to the Pearl River drainage of Louisiana and Mississippi. This taxon has long been a cryptic species, as it was considered part of $G$. pulchra before 1992 and part of $G$. gibbonsi until 2010. Graptemys pearlensis exhibits sexual dimorphism, with adult females being considerably larger (carapace length to $295 \mathrm{~mm}$ ) than adult males (CL to $121 \mathrm{~mm}$ ). In the 1960s and 1970s, the species was commonly found in higher abundance than the sympatric G. oculifera, a federally listed species. However, due to habitat degradation and the precipitous decline of native mollusks, the species is now found in lower numbers than G. oculifera throughout much of its range. The current IUCN Red List status is Endangered; however, very little is known about the natural history and ecology of the species, which will make conservation efforts challenging.

Distribution. - USA. Restricted to the Pearl River drainage of Mississippi and Louisiana.

Synonymy. - Graptemys pearlensis Ennen, Lovich, Kreiser, Selman, and Qualls 2010.

SubSPECIES. - None recognized.

STATUS. - IUCN 2015 Red List: Endangered (EN A1bcde+4bcde; assessed 2013); CITES: Appendix III (USA; as Graptemys spp.); US ESA: Not Listed.

Taxonomy. - The Pearl River Map Turtle, Graptemys pearlensis, was described by Ennen etal.(2010). The holotype is an adult male (Carnegie Museum 62162) from the Pearl River at State Highway 28 near Georgetown, Copiah County, Mississippi.Originally, G.pearlensis was recognized as part of G. pulchra by Baur (1893) and subsequent authors until
Lovich and McCoy (1992) described G. gibbonsi, which also included what is now recognized as $G$. pearlensis. Later, Ennen et al. (2010) split G. gibbonsi (sensu lato), restricting G.pearlensis to the Pearl River and G. gibbonsi (sensu stricto) to the Pascagoula River.Graptemyspearlensis is one of the five species within the pulchra clade, which

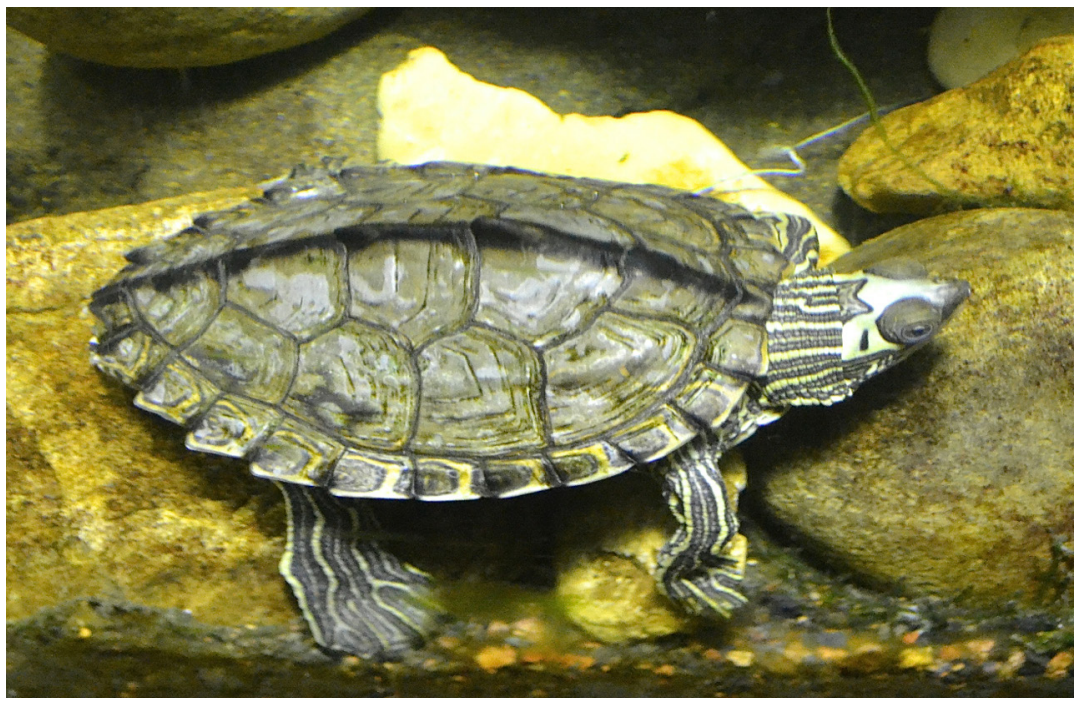

Figure 1. Adult male Graptemys pearlensis from the Tennessee Aquarium collection.

The unbroken black stripe on the median dorsal keel of G. pearlensis is a distinguishing characteristic. Photo by Joshua Ennen. 


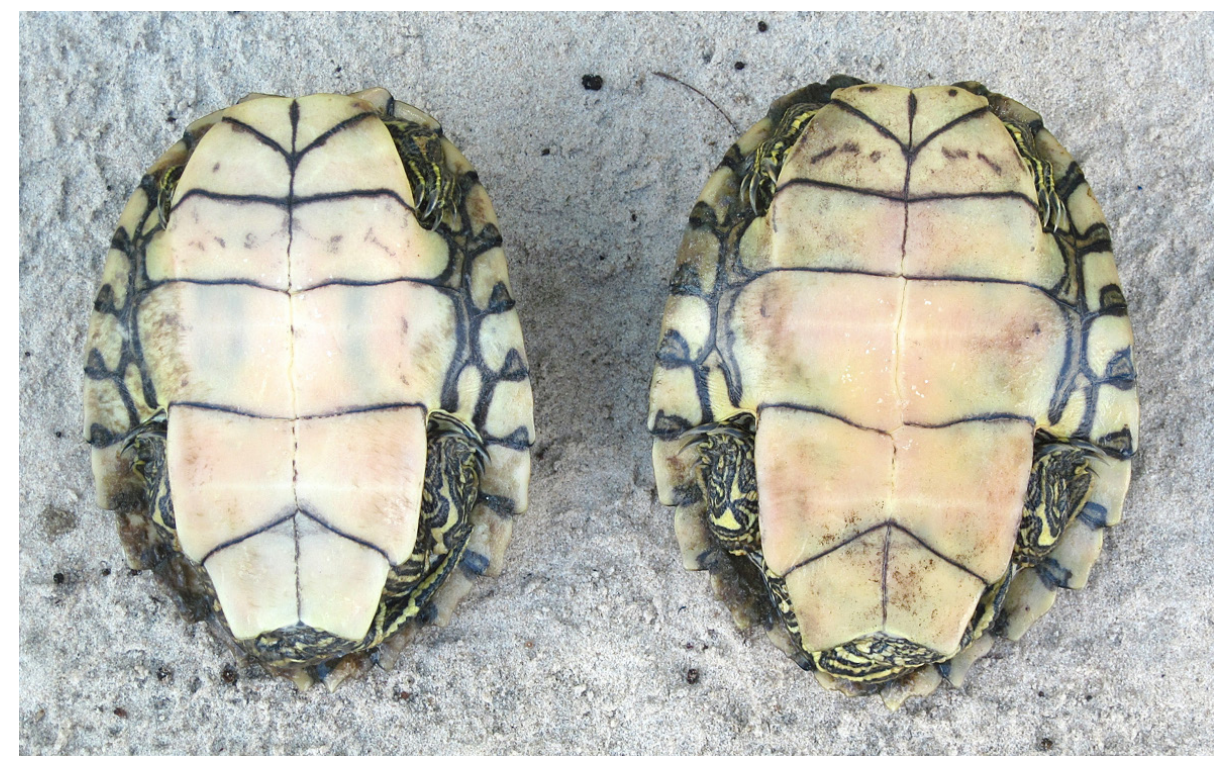

Figure 2. Plastron patterns of two male Graptemys pearlensis from the Pearl River near Monticello, Mississippi, USA. Photo by Robert Jones.

includes G.pulchra (sensu stricto), G. ernsti, G. barbouri, and G.gibbonsi (sensu stricto). Additional information on the taxonomic history of G.pearlensis can be found in Ennen et al. (2012). All five species can be differentiated on the basis of morphology and pigmentation patterns and they exhibit mtDNA divergence (Lovich and McCoy 1992; Lamb et al. 1994; Ernst and Lovich 2009; Ennen et al. 2010).

Description. - The Pearl River Map Turtle is a moderate-sized, highly aquatic freshwater turtle with carapace lengths reaching $295 \mathrm{~mm}$ and $121 \mathrm{~mm}$ for females and males, respectively. Graptemys pearlensis, similar to other species within the pulchra clade, possesses a high-domed shell with a median keel, which has salient spines on the posterior portions of the anterior vertebral scutes; the spines are considerably smaller than those of the sympatric $G$. oculifera (Ringed Sawback).

Key diagnostic features of $G$.pearlensis that distinguish it from G. gibbonsi are a complete dark stripe along the median keel (Fig. 1), narrower vertical yellow bar without conspicuous secondary concentric rings dorsally on each marginal scute (note, Table 5 in Ennen et al., 2010 inadvertently transposed the presence or absence of this character for the two species), vertical yellow bar on the 12th marginal scutes usually $50 \%$ or less than the scute length, and a nasal trident on the dorsal head surface behind the nares, a character which occurs more frequently in $G$. pearlensis than G. gibbonsi.

The background color of the carapace is olive green and vermiculations and circular yellow pigmentation are present on the distal portions of pleural scutes 1-3. The hingeless plastron is relatively flat and is pale yellow with some dark pigmentation along the seams (Fig. 2). The ground color of soft tissue is usually olive to black with yellow or yellowishgreen stripe patterns. Graptemys pearlensis, similar to $G$. gibbonsi, does not possess supraoccipital spots or anteriorly expanded dorsal paramedian neck stripes (Fig. 3). Another similarity between these two species is a large interorbital blotch connected to the large postorbital blotches on the head. Graptemys pearlensis is highly sexually dimorphic (Gibbons and Lovich 1990), where adult females are larger and possess conspicuously enlarged heads compared to adult males (Fig. 4).

The species within the pulchra clade differ based on several pigmentation features. A connection between the interorbital and postorbital blotches is found in G. pulchra, G. gibbonsi, and G. pearlensis. A nasal trident is found in $G$. ernsti, G. gibbonsi, and G.pearlensis, but less frequently in $G$. gibbonsi. Supraoccipital spots are usually present in G.ernsti but are absent in all other species. Unique to G. barbouri are a narrow interorbital blotch that ends anteriorly in a narrow

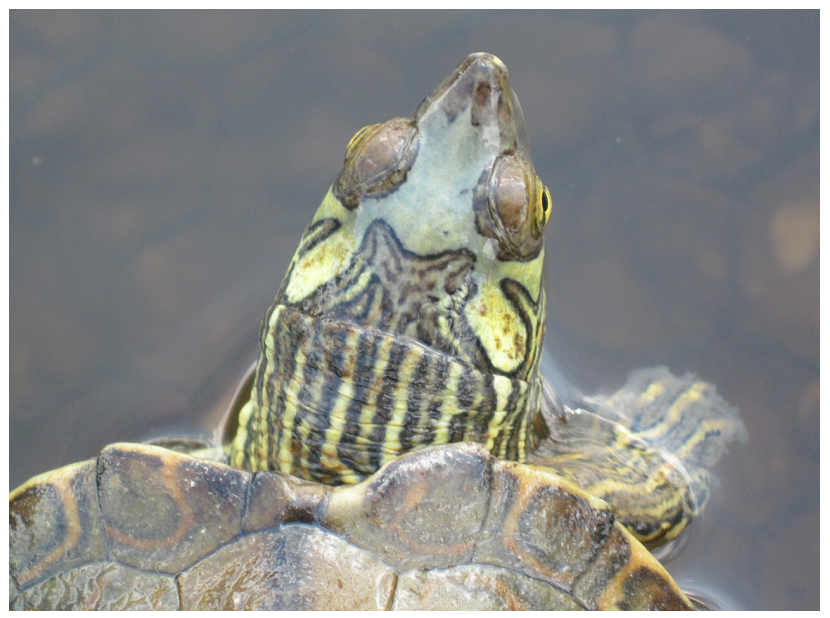

Figure 3. Head pattern of a male Graptemys pearlensis from the Pearl River near Monticello, Mississippi, USA. Photo by Robert Jones. 


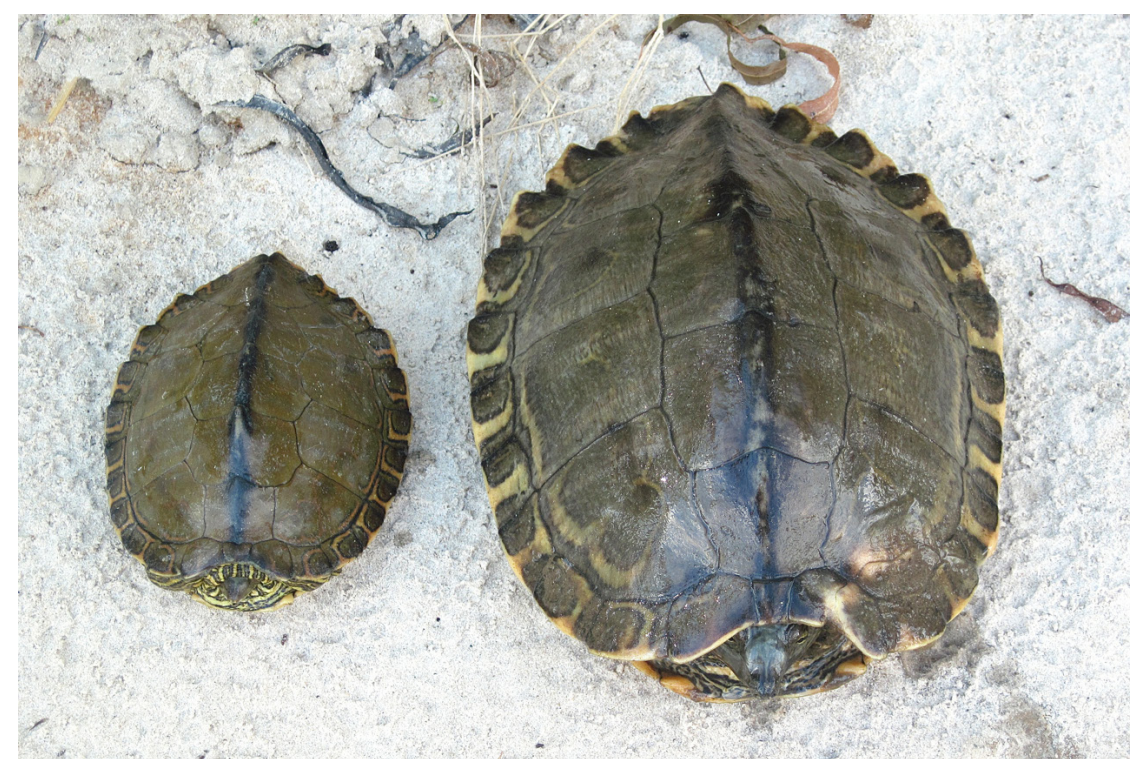

Figure 4. Graptemys pearlensis displays sexual dimorphism between males (left) and females (right). Both individuals were captured in the Pearl River near Monticello, Mississippi, USA. Photo by Robert Jones.

point, a curved or transverse bar under the chin, and a heartshaped pattern behind the interorbital blotch.

Distribution. - Graptemys pearlensis is endemic to medium-sized creeks and large rivers in the Pearl River drainage of Mississippi and Louisiana (Fig. 6). The largest populations, however, are found primarily in the Pearl and Bogue Chitto rivers. This species was reported within the Pearl River as far north as Neshoba County, Mississippi (Keiser 2000), including Ross Barnett Reservoir (Boyd and Vickers 1963). Downstream limits are within 14.5 river km of the Gulf of Mexico in the east Pearl River near the former town of Napoleon, Mississippi (Dickerson and Reine 1996; Ennen et al. 2010; W. Selman, pers. obs.). Individuals were reported throughout the Bogue Chitto River (Shively 1999) in Louisiana and into Walthall and Pike Counties, Mississippi (Ennen et al. 2010; Lindeman 2013). Within the range, $G$. pearlensis has also been reported from smaller rivers and

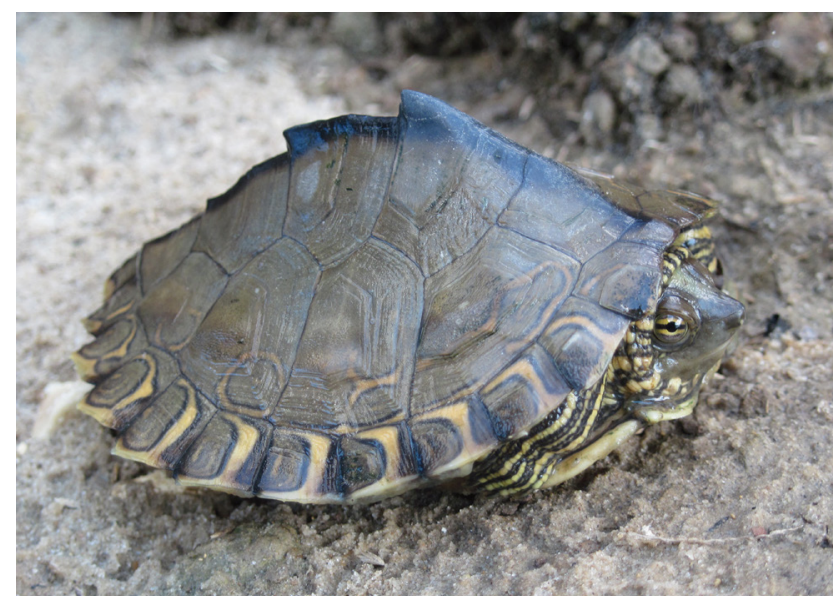

Figure 5. A yearling Graptemys pearlensis from the Pearl River, upstream of Monticello, Lawrence County, Mississippi. Photo by Robert Jones. creeks including the Strong River (Lindeman 2008), as well as Pushepatapa (Carr and Messinger 2002) and Lobutcha creeks (MMNS 15516). The questionable record from the Tickfaw River, reported by Dundee and Rossman (1989) was discussed further by Lovich and McCoy (1992).

Habitat and Ecology. - In general, a paucity of information is available regarding the natural history and ecology of the pulchra clade (Ennen et al. 2012; Lovich and Ennen 2013). Of the 58 recognized turtle species in the United States, the best-studied species in the pulchra clade is G. barbouri, which ranks 37th overall (Lovich and Ennen 2013). Their analysis did not differentiate between G. pearlensis and G. gibbonsi due to the lack of publications on the former as a result of its recent description as a separate taxon (sensu lato). Graptemys gibbonsi (sensu lato) was ranked 46th. Graptemys pearlensis is most abundant in large to medium-sized rivers/creeks, where basking sites (logs and snags; Lindeman 1999), nesting sites (sand bars), and food species (i.e., bivalves and gastropods) are common features of the habitat.

Graptemys pearlensis is a carnivorous species and exhibits a broader diet than G. gibbonsi (McCoy and Vogt, unpubl. data). Females and males likely exhibit different dietary preferences due to sexual dimorphism (Gibbons and Lovich 1990; Lindeman 2000). Females possess larger heads and alveolar widths and probably consume more mollusks, while males and smaller females are largely insectivores. Cagle (1952) reported stomach contents of two males, which consisted of only insect remains, while a juvenile female stomach included mollusks (clams and snails). Not separating males and females or standardizing for size, McCoy and Vogt (unpubl. data) found G. pearlensis consumed mostly scavenged fish (44\%) and equal portions by volume of insects and mollusks (25\%) in stomach contents. Detailed 


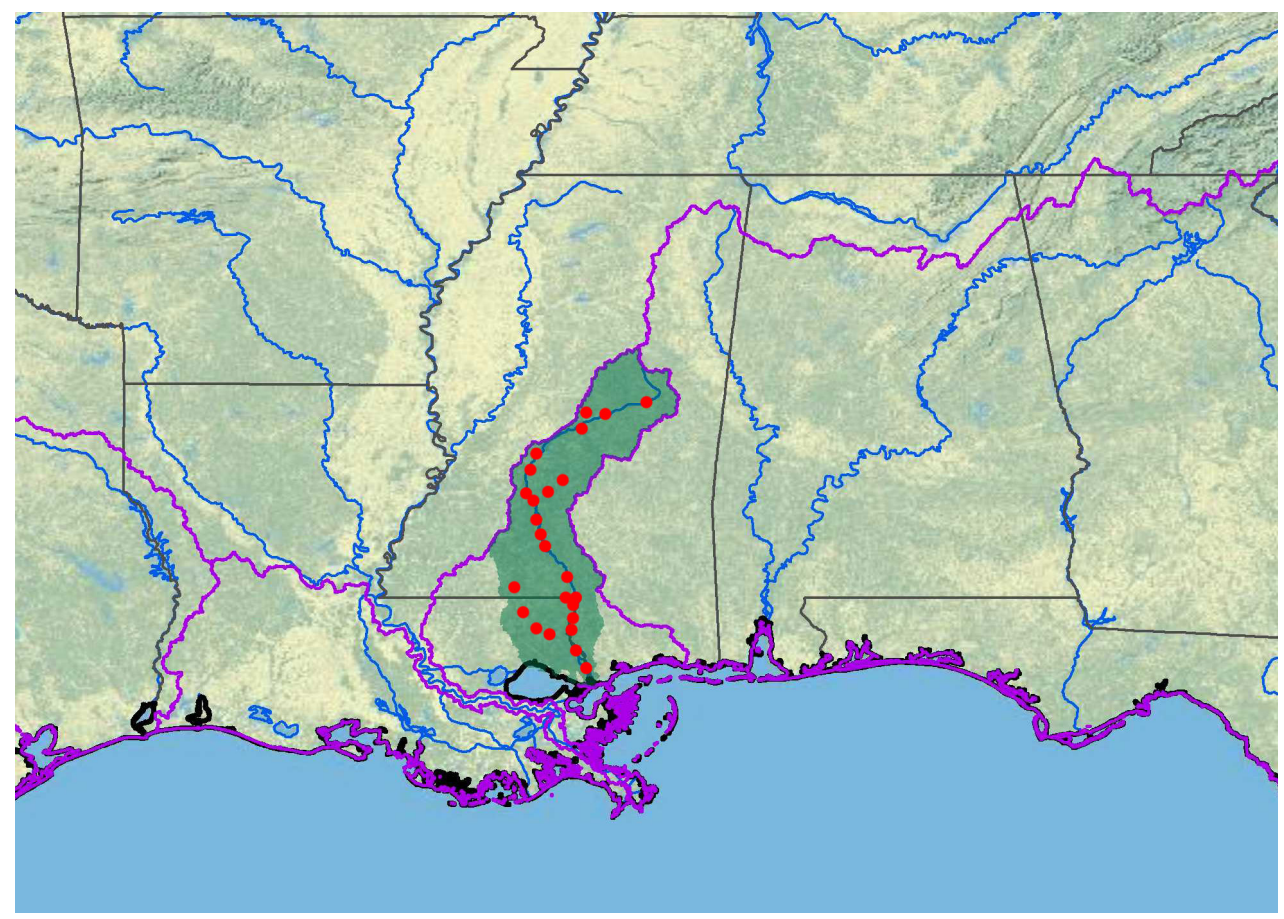

Figure 6. Distribution of Graptemys pearlensis in the Pearl River drainage of Louisiana and Mississippi, USA. Purple lines = boundaries delimiting major watersheds (level 3 hydrologic unit compartments $-\mathrm{HUCs}$ ); red dots = museum and literature occurrence records based on Iverson (1992) plus more recent data provided by Will Selman; green shading = projected distribution based on GIS-defined level 10 HUCs constructed around verified localities and then adding HUCs that connect known point localities in the same watershed or physiographic region, and similar habitats and elevations as verified HUCs (Buhlmann et al. 2009; TTWG 2014), and adjusted based on Selman's data.

dietary studies on contemporary populations are needed to further delineate the diet of G. pearlensis.

Turtles of the genus Graptemys are predominately diurnal. Although no data are available on adult movements or basking for G. pearlensis, the species is presumed to be diurnal, and basking behavior is likely similar to that of $G$. ernsti (Shealy 1976) and G. gibbonsi (Selman and Qualls 2007). For G. gibbonsi, preliminary data indicate that basking peaks at midday and in late afternoon, probably associated with abiotic temperatures (water and ambient), which appeared to overlap with the preferred basking period of $G$. flavimaculata (Lovich et al. 2009; Selman and Qualls 2007). At night, G. pearlensis is relatively inactive and clings to submerged snags and deadwood just below the surface (Chaney and Smith 1950). Anderson (1958) conducted a study on movement behavior of hatchling G.pearlensis with regards to photic response and water-approach behavior.

McCoy and Vogt (unpubl. data) observed gravid females from May to August in 1978 and 1979. Eggs are deposited in nest cavities constructed on sand bars above the water line, and average clutch size was 6.4 , which was smaller than reported in G. gibbonsi. Although not directly observed, females are presumed to produce multiple clutches in a given reproductive season. Upon dissection of a gravid female with 3 eggs, the specimen possessed 6 enlarged ovocytes suggestive of multiple clutches within the species. Cagle (1952) captured a gravid female with a plastron length of $170 \mathrm{~mm}$, which is similar to the smallest gravid G. gibbonsi female (179 $\mathrm{mm}$ PL, Lovich et al. 2009). Males attain sexual maturity at smaller sizes than females, around a plastron length of $89 \mathrm{~mm}$, (Cagle 1952). Egg width and length ranged from 25.0-27.0 $\mathrm{mm}$ and 46.0-47.3 $\mathrm{mm}$, respectively.

More recently, data on reproduction in G. pearlensis were collected incidentally during a study of reproduction in G. oculifera on the Pearl River in Mississippi (Jones 2006). Three fresh nests were found on 6,13, and 21 June on sandbars. The nests had been dug in relatively fine sand and were located from less than 7 to over $55 \mathrm{~m}$ from the edge of the river. The nests averaged $1.6 \mathrm{~m}$ from the closest vegetation, and the average depth to the bottom of the nest cavities was $16.3 \mathrm{~cm}$. The average size of five deposited clutches was 6.4 and ranged from 4-9 eggs. Average length, width, and mass of 33 eggs were $40.1 \pm 1.8 \mathrm{~mm}, 26.8 \pm 0.5$ $\mathrm{mm}$, and $16.4 \pm 1.2 \mathrm{gm}$, respectively. Five eggs incubated in the lab pipped an average of 62.8 days after deposition, and three clutches incubated in natural nests each pipped in 62 days. Emergence from the nest cavity for the three field clutches occurred on average in 69.3 days and ranged from 67-79 days. The five lab-reared G. pearlensis hatchlings averaged $36.6 \pm 1.0 \mathrm{~mm}, 31.2 \pm 1.3 \mathrm{~mm}, 32.8 \pm 1.5 \mathrm{~mm}$, and $11.3 \pm 1.0 \mathrm{gm}$ for carapace length, midline plastron length, total plastron length, and mass, respectively.

Little information is available on the growth rates of $G$. pearlensis. Cagle (1952) reported one hatchling that grew 

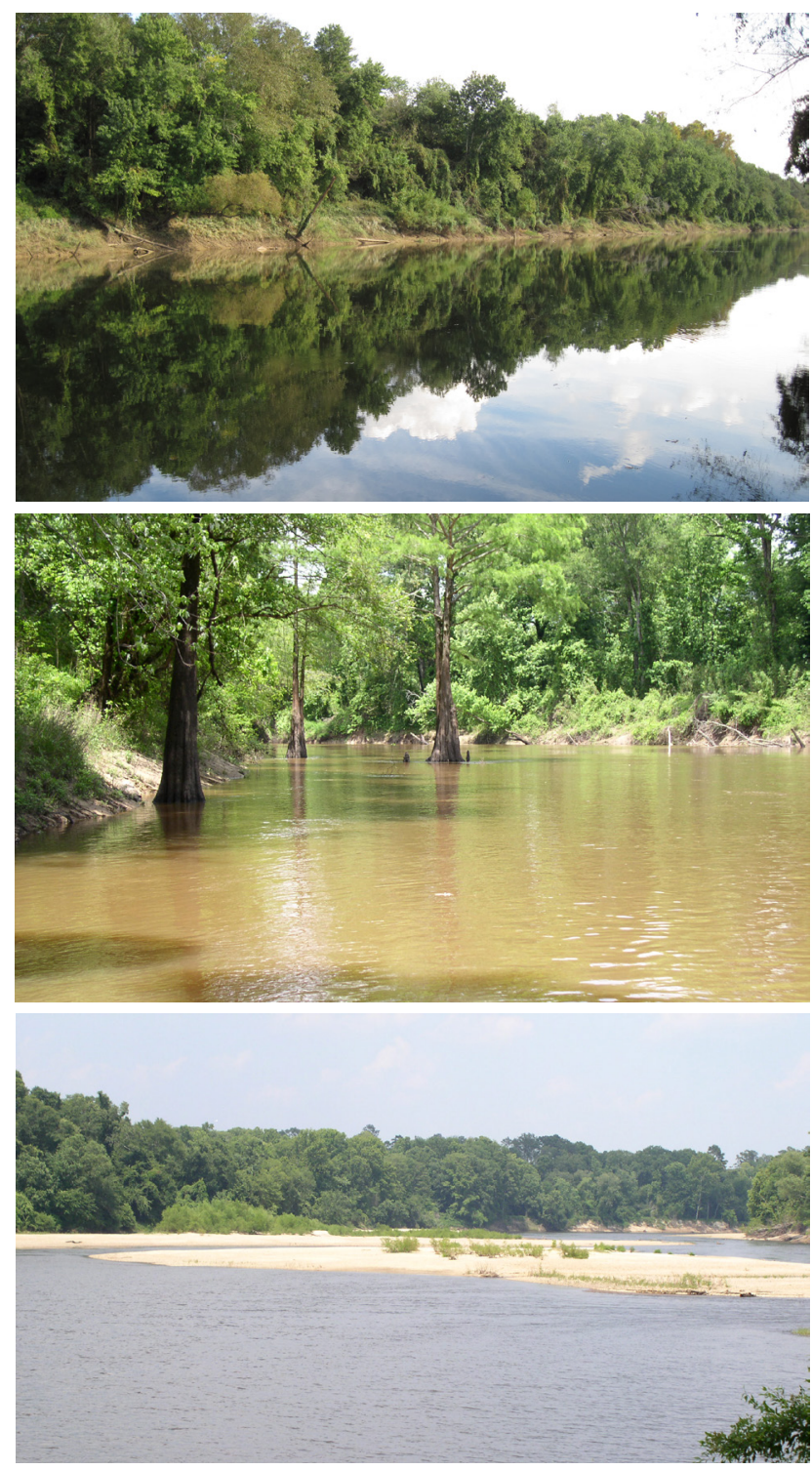

Figure 7. Habitats of Graptemys pearlensis in the Pearl River, Mississippi. Top: Type locality near Georgetown, Copiah County. This site is typical habitat with a wooded riparian zone and ample basking sites. Middle: Upper portion of the Pearl River near Carthage, Leake County; the species is found in relatively high densities at this site. Bottom: Upstream of Columbia, Marion County; sandbars provide nesting habitat and the gravel bar provides foraging opportunities, as it has a relatively dense population of freshwater mussels. Photos by Robert Jones.

$36.6 \mathrm{~mm}$ over a two-year period, growing $19.7 \mathrm{~mm}$ in the first season and $16.9 \mathrm{~mm}$ in the second.

Population Status. - In the 1950s, G. pearlensis appeared to be more abundant in the Pearl River (98 individuals) than Bogue Chitto River(12 individuals; Cagle 1952), where turtles were hand captured over an undisclosed time period. The Pearl River sample was skewed towards juveniles ( 75 individuals), and the sex ratio was approximately 1:1. Additionally, several studies reported that G. pearlensis was more abundant than the sympatric G. oculifera (Cagle 1952, 1953; Tinkle 1958).Cagle (1952) reported G.pearlensis (110 individuals) was 1.9 times more abundant than G. oculifera
(58 individuals) in the Pearl and Bogue Chitto rivers. In a later study of a Pearl River population, Cagle (1953) reported G.pearlensis (105 individuals) was 2.1 times more abundant than G. oculifera (51 individuals), where turtles were hand captured at night over an undisclosed time period. Likewise, Tinkle (1958) found G.pearlensis (57 individuals) 1.9 times more abundant than G. oculifera (30 individuals).

By the 1990s, basking densities of G. pearlensis were lower than those of G. oculifera, a federally listed species (Dickerson and Reine 1996; Lindeman 1998,1999; Shively 1999). Unlike previous trapping studies (i.e., Cagle 1952, 1953; Tinkle 1958), basking G.oculifera outnumbered basking G. pearlensis at all surveyed sites, particularly within the Upper and Lower Pearl River (28.6 to 1) and West Pearl River (4.1 to 1; Lindeman 1998, 1999). Similarly, Dickerson and Reine (1996) found G.pearlensis at lower densities than G. oculifera at two east Pearl River sites in Mississippi (125 G.pearlensis: 2501 G.oculifera) and seven sites in the West Pearl River, Louisiana (16 G. pearlensis: 534 G. oculifera); Dickerson and Reine's (1996) results were not unexpected as other authors have reported lower numbers of broad headed map turtle species in downstream regions relative to upstream regions (Selman and Qualls 2009; Lindeman 2013). In a survey that covered over $4.2 \mathrm{~km}$ of Pearl River shoreline, G.oculifera was the predominant basking species with $75.2 \%$ of the observations compared to $7.8 \%$ for $G$. pearlensis (Lindeman 1999). This same trend of G. oculifera outnumbering $G$. pearlensis was also reported within the Bogue Chitto River by Shively (1999) who reported fewer G. pearlensis (22\% of basking turtles) in comparison to $G$. oculifera (30\%); likewise, G. pearlensis was more abundant than G. oculifera in $38.4 \%$ of river bends examined. Historical population trends demonstrated that G. pearlensis was almost twice as abundant as G. oculifera in the 1950s and 1960 s, but by the 1970s, G. pearlensis was less common in comparison to G. oculifer $a$ and the trend continued into the 1980s and 1990s (Lindeman 1999).

Trapping data within the Pearl River also indicate that G. pearlensis population levels are lower than G. oculifera (Jones and Hartfield 1990; Selman and Qualls 2007). Using trapping data from Jones and Hartfield's (1990) earlier work, Selman and Qualls (2007) compared population densities of G. pearlensis over a 16-year period. Graptemys pearlensis was observed in higher numbers relative to G. oculifera in 1990 (1:1.15) compared to 2005-06 (1:5.39-6.34). Numbers of trapped G. pearlensis also declined, while G. oculifera numbers remained relatively stable.

Five sites on the Pearl River in Mississippi (Jones and Hartfield 1990) have been monitored periodically using basking traps since the late 1980s for G. oculifera and incidentally for G. pearlensis. In the late 1980s, average catch of G. pearlensis ranged from 1.8/day at Ratliff Ferry in the upper Pearl River basin to 9.6/day near Columbia in the 
lower part of the basin. In the mid-1990s, the catch of $G$. pearlensis had declined to 0.8 per day at Ratliff Ferry but remained relatively stable at Columbia at $9.7 /$ day. Trapping between 2000 and 2010 indicated that numbers remained at a low level at Ratliff Ferry (1/day) but declined to 5/day at Columbia. At the three other sites, numbers of G.pearlensis trapped per day have shown a similar decline at two of the sites and have remained relatively stable at only one, the most upriver site near Carthage. Another round of trapping was initiated in 2013, and preliminary data indicate that the decline at Ratliff Ferry and at another site just below Ross Barnett Reservoir is continuing.

Threats to Survival. - Habitat loss and degradation is a leading cause of population decline for many turtle species. Because of the unique life history traits of longlived species, most turtles are highly sensitive to slight perturbations that impact adult and sub-adult age classes (Congdon et al. 1993, 1994). This can include the removal of logs or snags, channelization, or impoundment, which eliminates habitat elements (basking and nesting sites) that are essential for survival (Lindeman 1999). In the Pearl River watershed, habitat loss and degradation have been caused by contaminants from urban and industrial sources, gravel mining in the Bogue Chitto and lower Pearl rivers (Shively 1999), and the modification of the downstream natural flow regime and its associated habitat changes caused by construction of the Ross Barnett Reservoir near Jackson. An additional impoundment just downstream of Ross Barnett Reservoir is currently in the planning stage, and construction of this new reservoir would further impact downstream flow regimes as well as G. pearlensis within the project boundary. Sedimentation and other anthropogenic alterations within the Pearl River drainage may have also adversely impacted the native mussel and gastropod populations (Jones et al.2005), thus decreasing a significant prey source for female G. pearlensis .

This species is susceptible to other anthropogenic impacts such as overexploitation and nest depredation by subsidized mesopredators. For example, G. gibbonsi (sensu lato) was found in Asian markets (Cheung and Dudgeon 2006) suggesting that exploitation may be international in scope. Selman and Qualls (2007) provided evidence that hundreds of G.pearlensis were collected for the pet trade by one person in 2006. Humans and alligators (Alligator mississippiensis) are the only significant predators of adult $G$. pearlensis, and shooting basking turtles may cause population reduction in local areas (Marion 1986). Eggs and hatchlings are the most vulnerable stages within a turtle's life, and the presumed predators of nests and hatchlings are likely to be very similar to those of G. gibbonsi (Lovich et al.2009) and other turtle species in southeastern United States.

Conservation Measures Taken. - The Pearl RiverMap Turtle is listed as a Species in Need of Management by the
State of Mississippi. No commercial take of this species is allowed, take for personal use is limited to four individuals, and total possession limit is four. This species has no specific regulatory status in Louisiana (Will Selman, pers. comm.). The IUCN Red List designation is Endangered (van Dijk, 2013). This species is listed by CITES under Appendix III for the USA, covering all Graptemys species (www.cites. org/eng/resources/species.html). Graptemys pearlensis cooccurs with G. oculifera over much of the latter's range, and any conservation measures implemented for G. oculifera will likely benefit $G$. pearlensis as well.

The Pearl River Map Turtle is found in several state managed areas in both Mississippi (Nanih Waiya Wildlife Management Area [WMA], Neshoba County; Pearl River WMA, Madison County; and Old River WMA, Pearl River County) and Louisiana (Pearl River WMA, St. Tammany Parish) and in the federal Bogue Chitto National Wildlife Refuge (St. Tammany Parish, Louisiana and Pearl River County, Mississippi). These areas all border the Pearl River, but no specific management for G. pearlensis occurs within any of them.

Conservation Measures Proposed. - Given the apparent decline of this species, status surveys should be conducted in the Pearl River watershed of both Mississippi and Louisiana with emphasis on determining the relative densities of $G$. pearlensis in the main stems of the Pearl and Bogue Chitto rivers. These surveys should focus on the extent to which $G$. pearlensis occupies smaller river and tributaries of the Pearl and Bogue Chitto rivers in both states. Due to the paucity of published data on the species (as reported by Lovich and Ennen 2013), future research should be conducted on G. pearlensis reproductive biology, movements, basking activity, food habits, and longevity. Special emphasis should be directed at understanding the relationship between bivalve and gastropod densities and distribution and the dietary preferences of G. pearlensis, particularly of adult females.

Captive Husbandry. - Graptemys pearlensis has been successfully maintained in captivity in the aquariums of the Mississippi Museum of Natural Science for several years, although captive propagation of this species has not been attempted. No special facilities nor diet other than what is used for most captive emydids have been employed. It should be noted that many of the Graptemys referred to as G. gibbonsi in the pet trade are likely G. pearlensis (Selman and Qualls 2007). Graptemys gibbonsi (sensu stricto) is endemic to the Pascagoula watershed in Mississippi and commercial take of that species has never been permitted. Louisiana had no restrictions on the capture and trade of $G$. gibbonsi (sensu lato), so the Graptemys captured and sold from that state were actually G. pearlensis. There remains some confusion about the identity of many specimens sold as G. gibbonsi (sensu lato) in Germany (Beate Pfau, pers. 
comm.), but if they are G.pearlensis, then captive propagation has successfully occurred in several breeding facilities in both Europe and the United States.

Current Research. - Current research is limited to population status and distribution studies (Edmund Keiser, unpubl. data; Lindeman, unpubl. data; Landry and Gregory, unpubl. data). Robert Jones has been conducting long-term population-level studies on G.oculifera since the early 1990s at several sites within the Pearl River drainage, but only has collected data on $G$. pearlensis incidental to $G$. oculifera (Jones, unpubl. data). Future research should focus on filling our knowledge gap on reproductive ecology, diet, movement ecology, longevity, and population genetics.

Acknowledgments. - We would like to thank the Tennessee Aquarium Conservation Institute and the Mississippi Department of Wildlife, Fisheries, and Parks for their support.

\section{LITERATURE CITED}

Anderson, P.K. 1958. The photic responses and water-approach behavior of hatchling turtles. Copeia 1958:211-215.

BAUR, G. 1893. Two new species of North American Testudinata. American Naturalist 27:675-677.

Boyd, C.E. AND Vickers, D.H. 1963. Distribution of some Mississippi amphibians and reptiles. Herpetologica 19:202-205.

Buhlmann, K.A., Akre, T.S., Iverson, J.B., Karapatakis, D., MitTERMEIER, R.A., GEORgEs, A., Rhodin, A.G.J., vAN DiJk, P.P., AND GibBons, J.W. 2009. A global analysis of tortoise and freshwater turtle distributions with identification of priority conservation areas. Chelonian Conservation and Biology 8:116-149.

CAGLE, F.R. 1952. The status of the turtles Gratpemys pulchra Baur and Graptemys barbouri Carr and Marchand, with notes on their natural history. Copeia 1952:223-234.

CAgle, F.R. 1953. The status of the turtle Graptemys oculifera (Baur). Zoologica 38:137-144.

CARr, J.L. And Messinger, M.A. 2002. Graptemys gibbonsi, Predation. Herpetological Review 33:201-202.

Chaney, A. And Smith, C.L. 1950. Methods for collecting map turtles. Copeia 1950:323-324.

Cheung, S.M. And Dudgeon, D. 2006. Quantifying the Asian turtle crisis: market surveys in southern China, 2000-2003. Aquatic Conservation: Marine and Freshwater Ecosystems 16:751-770.

Congdon, Dunham, A.E., and van Loben Sels, R.C. 1993. Delayed sexual maturity and demographics of Blanding's turtles (Emydoidea blandingii): implications for conservation and management of long-lived organisms. Conservation Biology 7:826-833.

Congdon, J.D., Dunham, A.E., And van Loben Sels, R.C. 1994. Demographics of common snapping turtles (Chelydra serpentina): implications for conservation and management of long-lived organisms. American Zoologist 34:397-408.

Dickerson, D.D. And Reine, K.J. 1996. Habitat assessment and relative abundance estimates for the ringed sawback turtle (Graptemys oculifera) in dredging sites of the West Pearl River Navigation Project (Louisiana). Final Report prepared for the US Army Engineer District, Vicksburg, MS, 52 pp.

Dundee, H.A. and Rossman, D.A. 1989. The Amphibians and Reptiles of Louisiana. Baton Rouge: Louisiana State University Press, 300 pp.
EnNen, J.R., Lovich, J.E., Kreiser, B.R., Selman, W., ANd Qualls, C.P. 2010. Genetic and morphological variation between populations of the Pascagoula Map Turtle (Graptemys gibbonsi) in the Pearl and Pascagoula rivers with description of a new species. Chelonian Conservation and Biology 9:98-113.

ENNEN, J.R., Lovich, J.E., AND BirKHEAD, R.D. 2012. Graptemys pearlensis Ennen, Lovich, Kreiser, Selman, and Qualls. Pearl River Map Turtle. Catalogue of American Amphibians and Reptiles 889:881-884.

ERnst, C.E. AND Lovich, J.E. 2009. Turtles of the United States and Canada. Second Edition. Baltimore: Johns Hopkins University Press, 827 pp.

GibBons, J.W. And Lovich, J.E. 1990. Sexual dimorphism in turtles with emphasis on the slider turtle (Trachemys scripta). Herpetological Monographs 4:1-29.

IVERSON, J.B. 1992. ARevised Checklist with Distribution Maps of the turtles of the World. Richmond, Indiana: Privately Printed, 363 pp.

JoNES, R.L. 2006. Reproduction and nesting of the endangered ringed map turtle, Graptemys oculifera, in Mississippi.Chelonian Conservation and Biology 5:195-209.

Jones, R.L. And HartField, P.D. 1990. Density and population structure of the ring sawback turtle, Graptemys oculifera (Baur): Year one. Unpublished report to Mississippi Department of Wildlife, Fisheries, and Parks. Jackson, MS, 34 pp.

Jones, R.L., Slack, W.T., And Hartfield, P.D. 2005. The freshwater mussels (Mollusca: Bivalvia: Unionidae) of Mississippi. Southeastern Naturalist 4:77-92.

KeISER, E.D. 2000. A survey on the Nanih Waiya Wildlife Management Area to locate turtles and turtle nesting sites, with emphasis on the ringed map turtle (Graptemys oculifera). Final Report submitted to the Mississippi Museum of Natural Science, Jackson, MS, 93 pp.

Lamb, T., Lydeard, C., Walker, R.B., and Gibbons, J.W. 1994. Molecular systematics of map turtles (Graptemys): a comparison of mitochondrial restriction site versus sequence data. Systematic Biology 43:543-559.

Lindeman, P.V. 1998. Of deadwood and map turtles (Graptemys): an analysis of species status for five species in three river drainages using replicated spotting-scope counts of basking turtles. Linnaeus Fund Research Report. Chelonian Conservation and Biology 3:137-141.

Lindeman, P.V. 1999. Surveys of basking map turtles Graptemys spp. in three river drainages and the importance of deadwood abundance. Biological Conservation 88:33-42.

LindEMAn,P.V.2000. Evolution of the relative width of the head and alveolar surfaces in map turtles (Testudines: Emydidae: Graptemys). Biological Journal of the Linnean Society 69:549-576.

Lindeman, P.V. 2008. Evolution of body size in the map turtles and sawbacks (Emydidae: Deirochelyinae: Graptemys). Herpetologica 64:32-46.

Lindeman, P.V. 2013. The Map Turtle and Sawback Atlas: Ecology, Evolution, Distribution, and Conservation. Norman, OK: University of Oklahoma Press, $460 \mathrm{pp}$.

Lovich, J.E. AND ENNEN, J.R. 2013. A quantitative analysis of the state of knowledge of turtles of the United States and Canada. Amphibia-Reptilia 34:11-23.

Lovich, J.E. AND McCoy, C.J. 1992. Review of the Graptemys pulchra group (Reptilia, Testudines, Emydidae), with descriptions of two new species. Annals of Carnegie Museum 61:293-315.

Lovich, J.E., Selman, W., And McCoy, C.J. 2009. Graptemys gibbonsi Lovich and McCoy 1992 - Pascagoula map turtle, Pearl River map turtle, Gibbons' map turtle. In: Rhodin, A.G.J., Pritchard, P.C.H., van Dijk, P.P., Saumure, R.A., Buhlmann, 
K.A., Iverson, J.B., and Mittermeier, R.A. (Eds.). Conservation Biology of Freshwater Turtles and Tortoises: A Compilation Project of the IUCN/SSC Tortoise and Freshwater Turtle Specialist Group. Chelonian Research Monographs No. 5, pp. 029.1-029.8.

Marion, K.R. 1986. Alabama map turtle. In: Mount, R.H. (Ed.). Vertebrate Animals of Alabama in need of Special Attention. Alabama Agricultural Experiment Station, Auburn University, pp. 50-52.

Selman, W. and Qualls, C. 2007. Distribution, status, and conservation of the Pascagoula map turtle (Graptemys gibbonsi). Technical report to the Mississippi Department of Wildlife, Fisheries, and Parks and the U.S. Fish and Wildlife Service, Jackson, MS, 37 pp.

Selman, W. And Qualls, C. 2009. Distribution and abundance of two imperiled Graptemys species of the Pascagoula River system. Herpetological Conservation and Biology 4:171-184.

SheALY, R.M. 1976. The natural history of the Alabama map turtle, Graptemys pulchra Baur, in Alabama. Bulletin of the Florida State Museum, Biological Science 21:47-111.

ShIVely, S.H. 1999. Survey for the ringed map turtle (Graptemys oculifera) in the Bogue Chitto River, Louisiana. Unpublished report to the Louisiana Natural Heritage Program and the Louisiana Department of Wildlife and Fisheries, Baton Rouge, LA, 50 pp.

TINKLE,D.W. 1958. The systematics and ecology of the Sternotherus carinatus complex (Testudinata, Chelydridae). Tulane Studies in Zoology 6:3-56.

TTWG [Turtle TAXonomy Working Group: van DiJk, P.P., Iverson, J.B., RHODIN, A.G.J., SHAFFER, H.B., AND BouR, R.]. 2014. Turtles of the world, 7th edition: annotated checklist of taxonomy, synonymy, distribution with maps, and conservation status. In: Rhodin, A.G.J., Pritchard, P.C.H., van Dijk, P.P., Saumure, R.A., Buhlmann, K.A., Iverson, J.B., and Mittermeier, R.A. (Eds.). Conservation Biology of Freshwater Turtles and Tortoises: A Compilation Project of the IUCN/SSC Tortoise and Freshwater Turtle Specialist Group. Chelonian Research Monographs 5(7):000.329-479.

VAN DiJK, P.P. 2013. Graptemys pearlensis. The IUCN Red List of Threatened Species 2013, e.T184437A8276246.

\section{Citation Format for this Account:}

ENNEn,J.R.,LOVICH, J.E., AND Jones, R.L. 2016. Graptemys pearlensis Ennen, Lovich, Kreiser, Selman, and Qualls 2010 - Pearl River Map Turtle. In: Rhodin, A.G.J., Pritchard, P.C.H., van Dijk, P.P., Saumure,R.A.,Buhlmann,K.A.,Iverson,J.B., and Mittermeier,R.A. (Eds.). Conservation Biology of FreshwaterTurtles and Tortoises: A CompilationProject of the IUCN/SSCTortoise andFreshwaterTurtle Specialist Group. Chelonian Research Monographs 5(9):094.1-8, doi:10.3854/crm.5.094.pearlensis.v1.2016, http://www.iucn-tftsg. org/cbftt/. 